\title{
BUSINESS DYNAMICS AND FIRM SURVIVAL IN EUROPEAN POST-TRANSITION ECONOMIES
}

\author{
KolaKoviC, M.; SiseK, B. \& TURUK, M.
}

Abstract: The interest in entrepreneurship and new firm formation has a long tradition in economic history. While dynamic relationship between entry and exit plays a crucial role in economic development, this interrelationship at the same time results in job creation by entering firms and job destruction by exiting firms. Understanding this interrelationship is fundamental in creating stimulating economic policy, although it takes time before the effect of new firm influences economic growth and boosts self-employment and employment overall. Survival of the firms plays important role in preserving jobs and economic growth, the key issues both in economic research and policy making. Therefore, the aim of this paper is to explore business dynamics through entry and exit processes and firm survival in European Post-transition economies. Most of the analysed countries were hit by economic crisis in the observed period and hence, the results should be interpreted in that context as well.

Key words: business dynamics, firm birth rates, firm death rates, firm survival, Posttransition economies
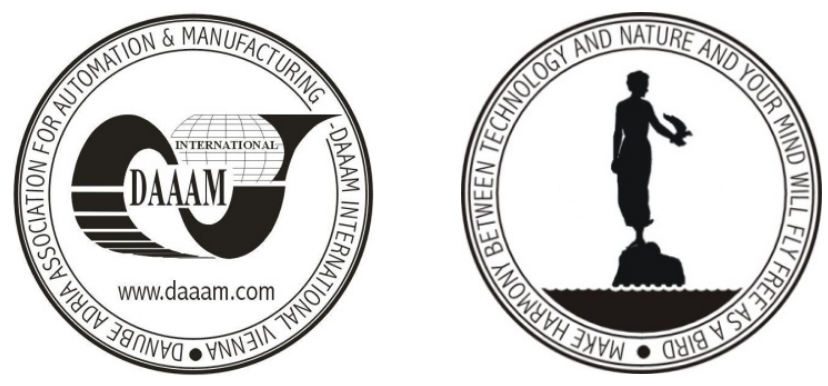

Authors' data: Univ. Prof. Dr. Sc. Kolakovic, M[arko]; Univ. Prof. Dr. Sc. Sisek, B[oris]; Turuk, M[laden], MA, University of Zagreb, Faculty of Economics and Business, Trg J. F. Kennedya 6, 10000, Zagreb, Croatia, mkolakovic@efzg.hr, bsisek@efzg.hr, mturuk@efzg.hr

This Publication has to be referred as: Kolakovic, M[arko]; Sisek, B[oris] \& Turuk, M[laden] (2014). Business Dynamics and Firm Survival in European PostTransition Economies, Chapter 33 in DAAAM International Scientific Book 2014, pp.409-422, B. Katalinic (Ed.), Published by DAAAM International, ISBN 978-3901509-98-8, ISSN 1726-9687, Vienna, Austria

DOI:10.2507/daaam.scibook.2014.33 
Kolakovic, M.; Sisek, B. \& Turuk, M.: Business Dynamics and Firm Survival in Eu...

\section{Introduction}

The interest in entrepreneurship and new firm formation has a long tradition in economic research. As a complementary approach to dominant comparative statics, business dynamics refers to the processes through which industries change over time and tries to reveal the basic underlying forces driving industry evolution. Entry of new firms increases competition and hence improve market conditions. Exit makes it possible to reallocate resources to new and more effective production, giving opportunities for new entering firms or for incumbent firms to expand their production. In this sense, exit can also be seen as a sign of a healthy economy where innovation and structural change move the economy forward (Nyström, 2006). Although it takes time before the effect of new firm entry influences economic growth and boosts self-employment and employment in the economy overall, the interrelationship in entry and exit rates is fundamental in creating economic and industrial policy regarding economic growth.

The aim of this work is to explore firm survival and business demography in European Post-transition countries ${ }^{1}$ that changed their economic systems from central planning to free market, and to analyse the cross-section differences in entry, exit and survival rates ${ }^{2}$ between four main sectors of most economies: industry, construction, wholesale and retail trade, and information and communication sector ${ }^{3}$. Present state and perspective of entrepreneurship depend on economic system and economic policy inasmuch as the former depend on entire social and political system (Ljubic \& Covic, 2000). According to NACE Rev. 2 classification, the industrial sector (B-E36) consists of the following activities: Mining and Quarrying (B), Manufacturing (C) ${ }^{4}$, Electricity, Gas, Steam and Air Conditioning supply (D) and Water collection, treatment and supply (E36). Construction sector (F) consist of construction of buildings, civil engineering and specialized construction activities, while Wholesale and retail trade sector $(\mathrm{G})$ consists of wholesale and retail trade and repair of motor vehicles and motorcycles, and wholesale and retail trade except of motor vehicles and motorcycles. Information and Communication sector $(\mathrm{J})$ consists of publishing, motion picture, video and television program production, sound recording and music publishing activities, programming and broadcasting activities, telecommunications, computer programming, consultancy and related activities, and information service activities.

Introductory section of the paper is followed by descriptive analysis of the observed Post-transition countries. Most of the analysed countries were hit by economic crisis in the four-year observed period from 2008-2011 and therefore, the

\footnotetext{
${ }^{1}$ These countries are: Bulgaria, Czech Republic, Estonia, Latvia, Lithuania, Hungary, Poland, Romania, Slovakia and Slovenia. Unfortunately, the data for Croatia, as the latest European Union Post-transition country was not available.

${ }^{2}$ One-year, two-year, three-year and four-year survival rates.

${ }^{3}$ Eurostat dataset is used to determine basic properties of business dynamics according to NACE Rev. 2 classification.

${ }^{4}$ Manufacture of: food products, beverages, tobacco products, textiles, wearing apparel, leather and related products, wood and furniture, paper and printed products, coke and refined petroleum products, chemicals and chemical products, pharmaceutical products, rubber and plastic products, metals, computer, electronic and optical products, machinery and equipment, motor vehicles and other transport equipment and other manufacturing.
} 
results should be interpreted in that context. While dynamic relationship between entry and exit plays a crucial role in economic development, this interrelationship at the same time results in job creation by entering firms and job destruction by exiting firms. Therefore, the entry and exit processes, as basic driving forces and fundamental issues of economic growth are empirically analysed. The main findings of the research are presented in the final section.

\section{Theory and previous work}

Fostering new enterprises and developing innovations are among the key elements of the Lisbon process. In order to monitor progress towards this goal indicators of firms' birth, death and survival were included in Eurostat database, referred to as 'business demography' (Schrör, 2007). The importance of business dynamics for economic development was first emphasized by Schumpeter (1934). According to his theory of creative destruction, growth, innovation and business dynamics are interconnected. The economy is being developed through the processes of competition and selection. Through innovation, firms gain competitive advantages and generate extra profits, which further leads to imitation and incentives for new firms to enter in particular sector. As a result of their entry, there is a decline in the average profits and firms are forced to further innovation. Those that fail have to leave the market and are replaced by new, innovative companies that introduce new ideas, products and technologies. Those that remain must adapt to new market conditions and increased competition.

Firm entry, their sustainability and growth are the prerequisite of achieving economic growth and development. There are many ways in which entrepreneurship can affect economic growth. Entrepreneurs can introduce new innovations when entering the market, which are manifested in new products or new production processes (Acs and Audretsch, 2003). Johnson and Parker (1996) and Ashcroft and Love (1996) found a significant positive correlation between firm entry and employment. Fritsch (1996) observed the former 74 West-German regions and found a positive correlation between the firm entry and increase in employment in the manufacturing sector in the long run but a negative correlation for the service sector. Reynolds et. al (2000) found a strong correlation between entrepreneurial activity (Total Entrepreneurial Activity) used in the GEM research and the growth of gross domestic product in 21 countries. The establishment of new enterprises can not only help to increase total employment, living standards and social well-being, but also to increase the comparative advantages of each sector due to higher competition. It is widely shared view that stimulating the founding of new firms will have a considerable positive impact on regional employment (Fritsch, 1997). Entry and exit dynamics potentially affects industrialization/deindustrialization, increase/decrease of gross domestic product and employment, and is an important determinant of economic growth. Fritsch and Mueller (2004) point out that the relationship between new firm formation and economic development is complex and has both direct and indirect effects on the economic performance of the market they enter. The direct or immediate effect refer to the new jobs that are created by the new firms while indirect 
Kolakovic, M.; Sisek, B. \& Turuk, M.: Business Dynamics and Firm Survival in Eu...

effects occur after some time through improved competitiveness of the industry. Newly established enterprises, even those that failed soon after they entered the market, may contribute to economic development through the positive effects they cause to the existing enterprises that, in order to protect from the new competition, have to innovate their production processes (Fritsch and Mueller, 2004).

The empirical literature on the explanation of business dynamics has concentrated mainly on entry and much less on exit (Nyström, 2007a, 2007b). In accordance with the theory of creative destruction (Schumpeter, 1934) beside entry of firms, it is important to observe their exit as well. Too many firms in a particular sector may indicate excessive competition where new, innovative enterprises are starting to replace incumbent, less competitive firms. The business potential is much larger among entrants than among incumbents, as new entry is often connected with innovations (Carlsson and Eliasson, 2001). Literature also shows that patterns of entry and exit differ significantly between different industries and over time. Most of the studies try to analyse business dynamics either in manufacturing sector or services, leaving construction and wholesale and retail trade sectors aside. Entry rates are expected to be on average higher in service sector than in the manufacturing industry (Audretsch and Fritsch, 2002). Some of the reasons are certainly found in the lower barriers of entry in service activities, as they often require less initial capital and smaller MES (minimum efficient scale). Lack of business dynamics in the manufacturing sector may have a negative effect for the economy, because it implies a lack of initiatives to create significant innovations. Specifically, the nature of innovation is different in the service sector and manufacturing sector. While in the service sector innovations are mainly related to minor changes in processes and procedures (De Jong et al., 2003), innovation in the manufacturing industry often mean radical changes, as they usually require previous greater investment in research and development.

Moreover, most studies analyse entry in the most developed countries (mostly due to better data availability) but entry dynamics in still less developed countries such as Post-transition economies may differ. Transition from central economy to free market system caused various difficulties to policy creators. As newly privatized firms tried to become more efficient, most Post-transition economies suffer from rising unemployment rates as state owned firms usually employed more people than necessary. Corruption was widely spread, especially during the first years of transition when state-owned enterprises started to become privately owned. Due to limited private initiative, many economies also suffered from a lack of entrepreneurial activity and new technologies required for the efficient production. Those who realized the entrepreneurial potential at the right time could have benefited, but this also led to a gap and increasingly rising inequality.

A variety of different factors may explain the probability of firms' survival. Macroeconomic environment, business cycles, entrepreneurial climate, firm-specific characteristics and the effect of other variables. The likelihood of survival should positively depend on the start-up size of an enterprise. The size of the firm is usually measured by the number of persons employed, its turnover or the initial amount of capital. Several studies relate the initial size of firms and the likelihood of their 
survival. Dunne et al. (1989) also show that higher initial size of the company means a greater likelihood of their survival. Geroski (1995) comes to the conclusion that the initial size of the firm affects its survival and growth as well. Previous research has also shown that less than $50 \%$ of enterprises survive on the market for five years (Dunne et al., 1989), while less than $40 \%$ of enterprises manage to survive six years after their establishment (Phillips and Kirchhoff, 1989). Also, older enterprises show a lower rate of exit from the sector than the newly-founded, which means that the chances for survival of enterprises increase with their age.

The focus of this analysis is on the smallest enterprises, those that according to Eurostat database had 1-4 persons employed in the observed period. Acs (1992) explains the importance of small businesses in the modern economy and states that small businesses play an important role in the economy as they act, through their entrepreneurial activity, as agents of change. Several studies emphasize that in the last 25 years innovation advantages shifted from large to small businesses, as new technologies reduced the importance of economies of scale in many sectors (Meijaard, 2001). Moreover, because of their innovations encouraged activities, they have an important role in generating new jobs. It is of utter importance to stimulate small business dynamics and growth, and to try to relief the difficulties they are faced with. Theories suggest that smaller firms have to deal with disadvantages of scale, which force them either to grow or to exit the market (Strotmann, 2007). Among the biggest problem is that smaller firms usually have more difficult access to finance and higher capital restrictions that could lead to their insolvency and illiquidity. Moreover, lack of highly qualified employees is also further argument theory suggest while trying to explain the lower probability of survival for smaller firms. Therefore, through data mining and descriptive analysis we proceed to identifying business demography and firm survival of the smallest firms in the Post-transition economies.

\section{Business demography analysis}

Eurostat business demography indicators (birth rates, death rates and survival rates) provide information on firm births, deaths and survivability at a relatively detailed activity level for enterprises of various types of ownerships and size-classes. Birth rate represents the number of real enterprise births of year $n$, divided by the population of active enterprises of year $n$. Death rate represents the number of real enterprise deaths of year $n$ divided by the population of active enterprises of year $n$. The enterprise churn rate is compiled as the sum of the enterprise birth rate and the enterprise death rate.

This section analyses birth, death and churn rates for enterprises that had at least one or more persons employed. Although enterprises were divided into three categories by size (1-4, 5-9 and 10+ persons employed), the focus will only be on the smallest enterprises, those that had 1-4 persons employed in the observed period, as they are expected to operate in the most dynamic business environment. Business demography data of the above mentioned enterprises in Post-transition economies for 
Kolakovic, M.; Sisek, B. \& Turuk, M.: Business Dynamics and Firm Survival in Eu... the 2008-2011 period $^{5}$ is presented in Tab. 1 (Birth=enterprise birth rate, Death=enterprise death rate, Churn=churn rate).

\begin{tabular}{|l|r|r|r|r|r|r|r|r|r|r|}
\hline Country & BG & CZ & EE & LV & LT & HU & PL & RO & SK & SI \\
\hline Industry (NACE sectors B-E) \\
\hline Birth & 10.33 & 6.30 & 6.69 & 14.01 & 7.32 & 17.93 & 5.39 & 9.65 & 4.46 & 15.93 \\
\hline Death & 8.57 & 4.27 & 8.42 & 10.99 & 8.09 & 12.42 & 6.99 & 13.05 & 4.08 & 7.80 \\
\hline Churn & 18.9 & 10.57 & 15.11 & 25.00 & 15.41 & 30.35 & 12.38 & 22.70 & 8.54 & 23.73 \\
\hline Construction (NACE sector F) \\
\hline Birth & 15.02 & 7.12 & 7.76 & 13.53 & 9.98 & 20.43 & 8.27 & 14.69 & 10.69 & 21.66 \\
\hline Death & 7.34 & 4.89 & 13.76 & 13.07 & 12.19 & 21.28 & 7.70 & 17.51 & 8.72 & 7.61 \\
\hline Churn & 22.36 & 12.01 & 21.52 & 26.60 & 22.17 & 41.71 & 15.97 & 32.20 & 19.41 & 29.27 \\
\hline Wholesale and retail trade (NACE sector G) \\
\hline Birth & 10.42 & 6.27 & 7.33 & 13.40 & 10.04 & 15.86 & 5.83 & 8.50 & 5.40 & 17.30 \\
\hline Death & 7.25 & 5.36 & 9.40 & 8.63 & 9.93 & 13.18 & 7.45 & 10.98 & 4.90 & 8.60 \\
\hline Churn & 17,67 & 11,63 & 16,73 & 22,03 & 19,97 & 29,04 & 13,28 & 19,48 & 10,30 & 25,90 \\
\hline Information and communication (NACE sector J) \\
\hline Birth & 11.89 & 5.73 & 9.75 & 18.57 & 7.08 & 21.43 & 10.40 & 10.03 & 8.83 & 23.18 \\
\hline Death & 5.42 & 3.13 & 7.08 & 6.19 & 5.91 & 10.19 & 6.14 & 11.09 & 3.41 & 8.85 \\
\hline Churn & 17,31 & 8,86 & 16,83 & 24,76 & 12,99 & 31,62 & 16,54 & 21,12 & 12,24 & 32,03 \\
\hline
\end{tabular}

Tab. 1. Business demography in European Post-transition countries, 2008-2011 average (enterprises with 1-4 persons employed)

In the industrial sector, Hungary (17.93\%), followed by Slovenia (15.93\%), had the highest rates of new firm formation (with 1-4 persons employed), while the lowest industrial birth rates were recorded in Slovakia (4.46\%) and Poland (5.39\%). The highest firm closure rates in industrial sector were recorded in Romania $(13.05 \%)$, while Slovakia had the lowest enterprise death rate $(4.08 \%)$ on average in the observed period. Hungary, followed by Latvia had the most turbulent industrial environment, characterized by high enterprise birth and death rates. On the other side, Slovakia and Czech Republic had the least turbulent environment.

In the construction sector, Slovenia had the highest small enterprise birth rate (21.66\%), followed by Hungary (20.43\%), while the lowest birth rates were recorded in Czech Republic (7.12\%) and Estonia (7.76\%). The highest firm closure rates in construction sector were recorded in Hungary (21.28\%), while Czech Republic had the lowest enterprise death rate $(4.89 \%)$ on average in the observed period. Hungary, followed by Romania had the most turbulent environment in the construction sector, while Slovakia and Czech Republic had the least turbulent environment.

In the wholesale and retail sector, Slovenia (17.30\%), followed by Hungary (15.86\%), had the highest rates of new small firm formation, while the lowest birth rates were recorded in Slovakia (5.40\%), followed by Poland $(5.83 \%)$. The highest firm closure rates in wholesale and retail sector were recorded in Hungary (13.18\%), while Slovakia had the lowest enterprise death rate $(4.90 \%)$ on average in the

\footnotetext{
${ }^{5}$ This was the latest available data at the time of this publication.
} 
observed period. Hungary, followed by Slovenia had the most turbulent environment, characterized by high enterprise birth and death rates. On the other side, Slovakia and Czech Republic had the least turbulent environment.

In the information and communication sector, Slovenia (23.18\%), followed by Hungary $(21.43 \%)$, had the highest rates of new small firm formation, while the lowest birth rates were recorded in Czech Republic (3.13\%), followed by Slovakia (3.41\%). The highest firm closure rates in information and communication sector were recorded in Romania (11.09\%), while Czech Republic had the lowest enterprise death rate $(3.13 \%)$ on average in the observed period. Slovenia, followed by Hungary had the most turbulent environment, characterized by high enterprise birth and death rates. On the other side, Czech Republic and Slovakia had the least turbulent environment.

Average birth (BR1-4) and death (DR1-4) rates by different sectors for enterprises with 1-4 persons employed in the 2008-2011 time period, are shown on Fig. 1.

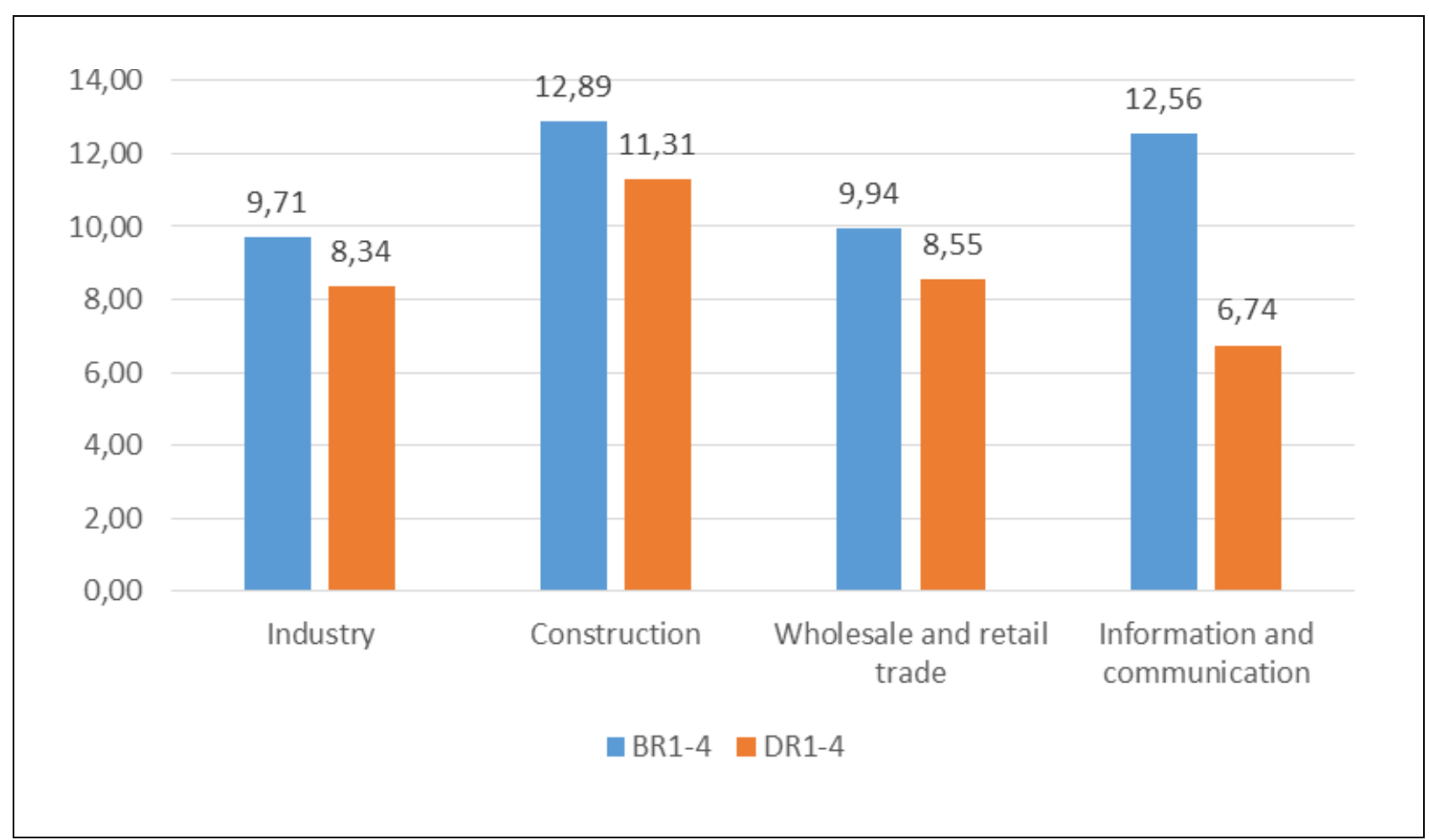

Fig. 1. Average enterprise birth and death rates by sectors (\%), 2008-2011

Construction sector had the highest birth rates but also the highest death rates, $12.89 \%$ (and $11.31 \%$ respectively) on average, making it the most dynamic sector from the analysed sectors. Information and communication sector had also very high average birth rates, but the lowest death rates (6.74\%), making it the most crisisresistant sector.

Average birth and death rates for enterprises with 1-4 persons employed in the four-year observed 2008-2011 time period, for each Post-transition country, are shown on Fig. 2. 
Kolakovic, M.; Sisek, B. \& Turuk, M.: Business Dynamics and Firm Survival in Eu...

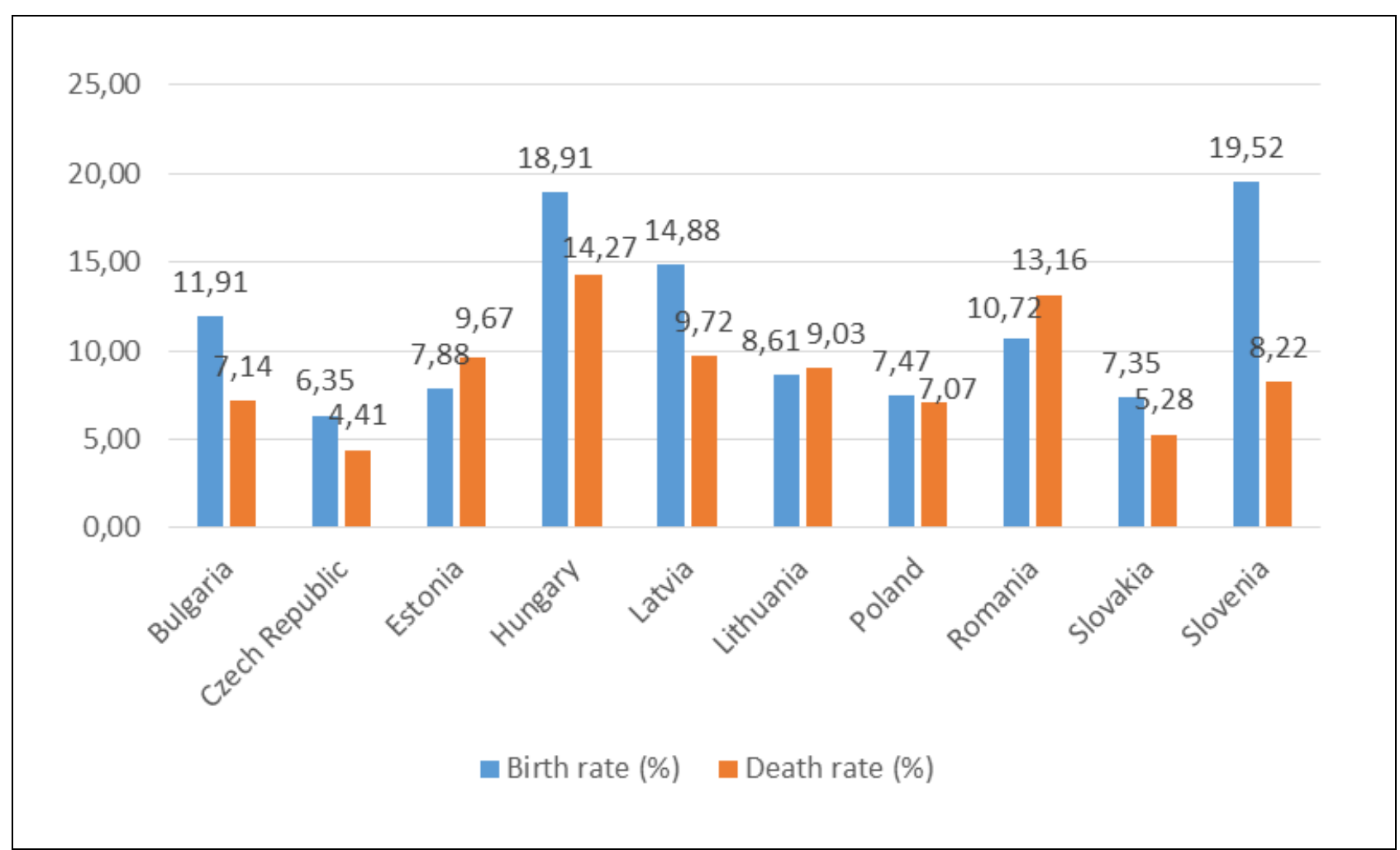

Fig. 2. Enterprise birth and death rates by countries (\%), 2008-2011 average

Czech Republic had the lowest both average birth (6.35\%) and death rates (4.41\%) among the analysed countries, making it the least dynamic economy. Slovakia's business dynamic could also be classified as stable as it had the second lowest average birth (7.35\%) and death rates (5.28\%). On the other side, Slovenia had the highest average enterprise birth rates (19.52\%), followed by Hungary (18.91\%). Hungary (14.27\%) and Romania (13.16\%). Only Estonia, Lithuania and Romania recorded higher average enterprise death rates than birth rates, which makes them the least favourable countries for business in the time of crisis. The highest positive difference between enterprise birth and death rates was recorded in Slovenia, while Romania has the highest negative difference.

\section{Firm survival analysis}

Survival rate is the percentage of all real enterprise births in year $n-1(n-2, n-3$, $n-4)$ which are still active in year $n$. Average firm survival rates for Post-transition countries for the 2008-2011 time period, for enterprises with 1-4 persons employed, is presented in Table 2 (SR1=one-year survival rate, SR2=two-year survival rate, $\mathrm{SR} 3=$ three-year survival rate, $\mathrm{SR} 4=$ four-year survival rate).

\begin{tabular}{|l}
\begin{tabular}{|l|c|c|c|c|c|c|c|c|c|c|}
\hline $\begin{array}{c}\text { Count } \\
\text { ry }\end{array}$ & BG & CZ & EE & LV & LT & HU & PL & RO & SK & SI \\
\hline \\
Industry (NACE sectors B-E) \\
\hline SR1 & 88.32 & 94.41 & 90.60 & 95.48 & 82.42 & 86.93 & $\begin{array}{r}91.9 \\
1\end{array}$ & 86.42 & 97.23 & 74.15 \\
\hline
\end{tabular}
\end{tabular}




\begin{tabular}{|c|r|r|r|r|r|r|r|r|r|c|}
\hline SR2 & 76.98 & 87.27 & 77.94 & 87.58 & 70.52 & 72.17 & $\begin{array}{r}79.6 \\
1\end{array}$ & 71.67 & 90.89 & 68.17 \\
\hline SR3 & 68.29 & 81.58 & 69.47 & 80.12 & 62.47 & 63.53 & $\begin{array}{r}67.8 \\
1\end{array}$ & 60.07 & 86.00 & 62.96 \\
\hline SR4 & 61.11 & 76.26 & 64.18 & 76.52 & 56.77 & 57.57 & $\begin{array}{r}60.8 \\
6\end{array}$ & 55.07 & 80.16 & 55.42 \\
\hline
\end{tabular}

Tab. 2. Firm survival rates in European Post-transition countries, 2008-2011 average (enterprises with 1-4 persons employed)

Early experiences show that rare countries managed to stabilize their economic movement while implementing economic liberalization (Benic, 1997). In the industrial sector, Slovakia (97.23\%), followed by Latvia (95.48\%), had the highest one-year survival rates while the lowest survival rates were recorded in Slovenia $(74.15 \%)$ and Lithuania (82.42\%). Similar results are obtained in two-year survival rate analysis, although with lower rates. The highest three-year survival rates were recorded in Slovakia (86.00\%), while Romania had the lowest survival rates $(60.07 \%)$. Similar results can be found in four-year survival rate analysis. In Slovakia, for example, four out of five enterprises still operate four years after their establishment, while almost every second enterprise in Romania had to close four years after it has started to operate.

In the construction sector, Slovakia (97.06\%), followed by Latvia (93.92\%), had the highest one-year survival rates while the lowest survival rates were recorded in Slovenia $(76.39 \%)$ and Hungary $(61.39 \%)$. Latvia has the highest two, three and fouryear survival rates $(85.50 \%, 82.28 \%$, and $76.39 \%$ respectively) while Hungary has the lowest two and three-year survival rates $(61.39 \%$ and $50.36 \%)$. The lowest fouryear survival rates were recorded in Lithuania, where more than half enterprises have not survived four years after they had been established. Interestingly, the same 
percentage of enterprises survived in Slovenia one year after their establishment and in Latvia four years after their establishment.

In the wholesale and retail sector, Slovakia had the highest one and two-year survival rates $(96.37 \%$ and $87.46 \%$ ), followed by Latvia. The lowest one and twoyear survival rates were recorded in Slovenia $(72.21 \%$ and $64.07 \%)$ and Lithuania (86.01\% and $67.47 \%)$. The highest three-year survival rates were recorded in Latvia (80.67\%), while Romania had the lowest survival rates $(60.26 \%)$. Latvia had the highest four-year survival rate $(74.76 \%)$ as well, while Slovenia had the lowest $(50.56 \%)$. Every second enterprise had to close down their activity in the wholesale and retail sector four years after they had been established, while at the same time period every fourth enterprise had to close in Latvia.

In the information and communication sector, Slovakia had the highest one, two, three and four year survival rates $(97.87 \%, 94.04 \%, 91.60 \%$ and $85.48 \%$ respectively). The lowest one and two year survival rates were recorded in Slovenia (80.75\% and $72.40 \%)$. Romania had the lowest three-year survival rates $(65.26 \%)$, while Estonia had the lowest four-year survival rates (57.79\%).

Average four-year survival rates by different sectors for different size-class enterprises in the four-year observed 2008-2011 time period, for Post-transition countries, are shown on Fig. 3.

Information and communication sector is the most stable sector from the analysed sectors as $67.71 \%$ of enterprises that had 1-4 persons employed managed to survive four-years after they had been established. Only in the ICT sector this number grows with all enterprise size-classes $(72.90 \%$ for enterprises with $5-9$ persons employed and $75.37 \%$ for enterprises with 10 or more persons employed managed to survive four-years after they had been established).

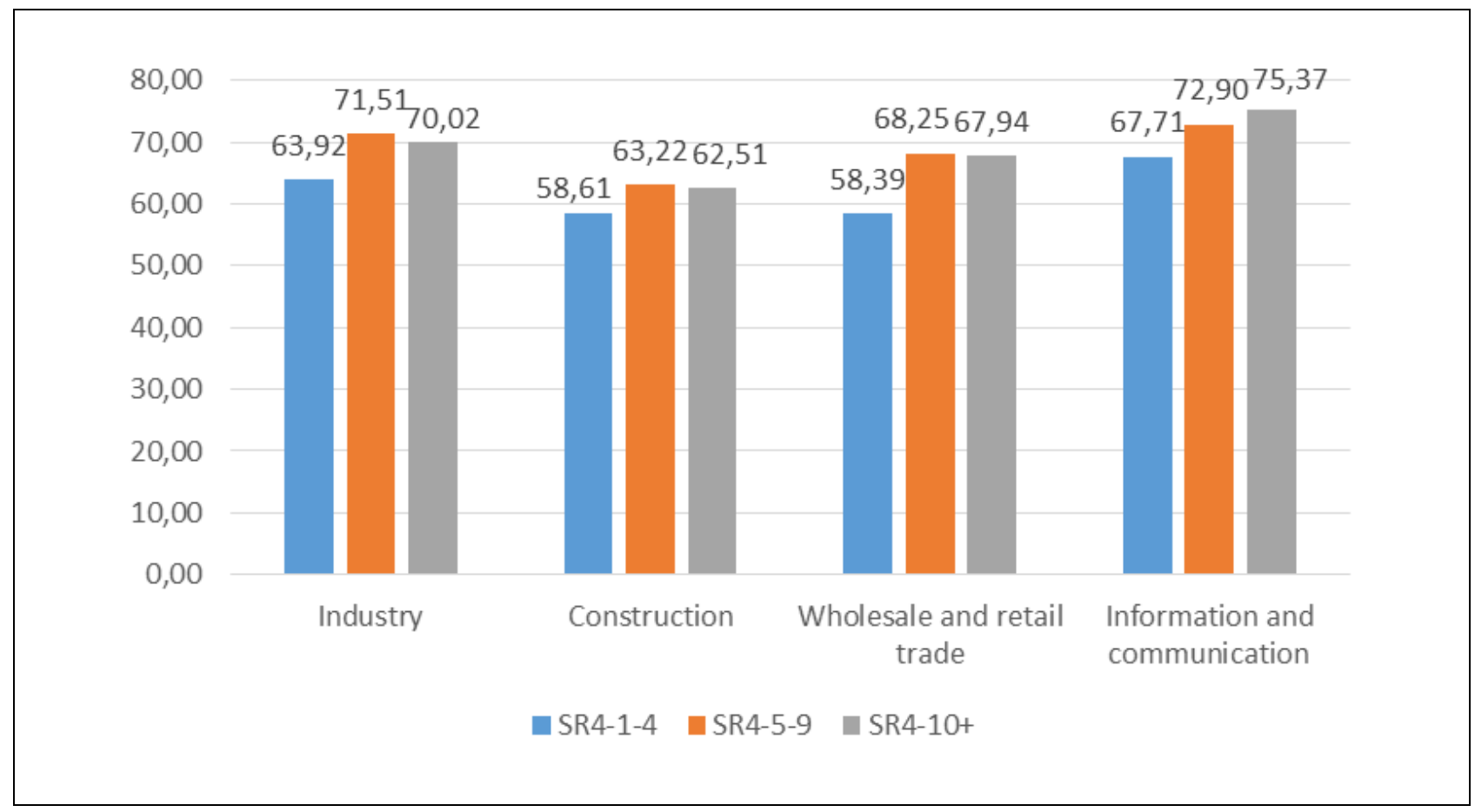

Fig. 3. Average enterprise four-year survival rates by sectors (\%), 2008-2011 
In other sectors survival rates are higher for enterprises with 5-9 than 1-4 persons employed, but slightly lower for enterprises with 10 or more than 5-9 persons employed. Interestingly, although the process of deindustrialization is often emphasized, industrial sector had relatively high enterprise survival rates. Construction sector had on average the lowest four-year survival rates in the observed period and it was the sector that was the most affected by economic crisis. Only $58.61 \%$ of enterprises with 1-4 persons employed survived four years after their establishment (63.22\% with 5-9 and $62.51 \%$ with more than 10 persons employed).

Total observed four sector average enterprise survival rates by year of establishment for the smallest, and though most affected enterprises are shown on Fig. 4.

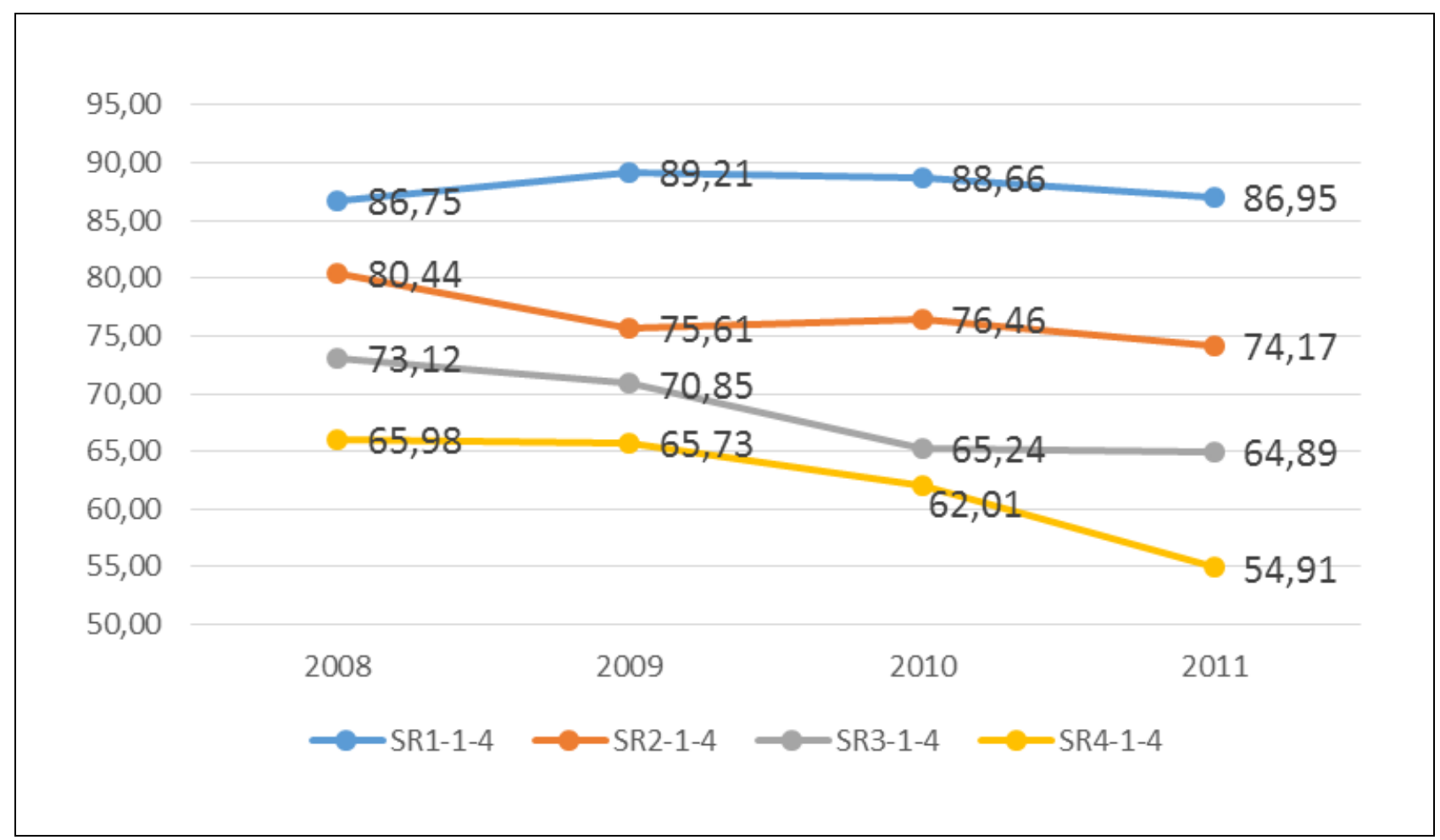

Fig. 4. Average enterprise survival rates by year of establishment (\%), 2008-2011

One-year survival rates slightly increased in the observed period (from $86.75 \%$ to $86.95 \%$ ). Two, three and four-year survival rates show negative trend. While in 2008 80.44\% of enterprises survived two years from establishment, this number fell to $74.17 \%$ in 2011 . Similarly, average three-year survival rates fell from $73.12 \%$ in 2008 to $64.89 \%$ in 2011 . This decrease is even more exaggerated for four-year survival rates. On average, only $54.91 \%$ of enterprises managed to survive four-years after they were established in 2011 (contrary to 65.98\% in 2008). This is worrying as almost every second enterprise on average had to close four years after it had been established.

Average enterprise one, two, three and four-year survival rates by Posttransition countries are shown on Fig. 5. 
Kolakovic, M.; Sisek, B. \& Turuk, M.: Business Dynamics and Firm Survival in Eu...

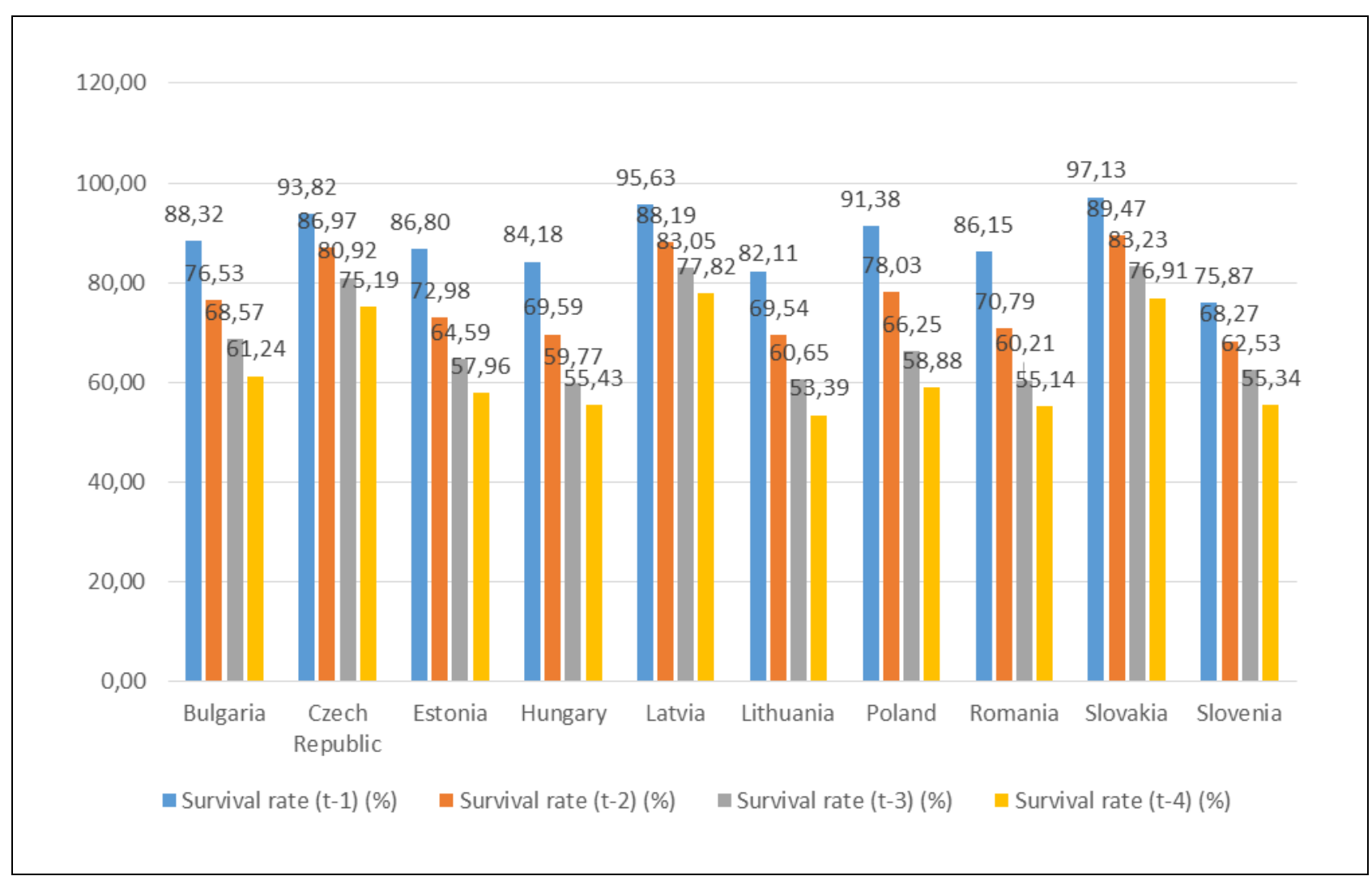

Fig. 5. Average enterprise survival rates by Post-transition countries (\%), 2008-2011

Slovakia had the highest survival rates among the countries observed $(97.13 \%$ of enterprises survive one-year after their establishment, $89.47 \%$ survive the second year, $83.23 \%$ the third, and $76.91 \%$ of enterprises survive four-years after their establishment). Enterprises in Czech Republic and Latvia have also among the highest survival rates, while Poland has high one-year survival rates that rapidly fall with time. Despite having the highest GDP per capita from the observed countries, Slovenia has on average the lowest survival rates.

\section{Conclusion}

The importance of business dynamics for economic development has a long tradition in both theoretical and empirical economic research. Firm entry, their sustainability and growth are the prerequisite of achieving economic growth and development. The focus of this analysis is on the smallest enterprises, as they are, due to their innovations and flexibility, attributed to be the agents of change in contemporary economy. Most of the previous studies analysed entry in the most developed countries, mainly due to better data availability, but the entry dynamics in still less developed countries such as Post-transition economies is still to be further analysed.

Enterprise birth rates are continuously higher than death rates. Even in the recession that hit most of the countries, the number of enterprises is continuously increasing. The highest birth rates were registered in construction and information and communication activities. The highest death rates were registered in construction as well, while the activities of information and communication registered the lowest 
percentage of closed enterprises. Construction sector is hence, the most dynamic sector from the analysed sectors. Information and communication sector had very high average birth rates, but the lowest death rates, making it the most crisis-resistant sector. The highest average birth rate in the observed period was registered in Slovenia, while the lowest was registered in Czech Republic. The highest average death rate in the observed period was registered in Hungary, while the lowest was registered in Czech Republic. The highest survival rates were registered in information and communication activities, while the lowest were registered in the construction sector. The probability of survival increases with the initial size of enterprises as well. The highest percentage of survival rates in the observed period was registered in Slovakia, while the lowest was registered in Lithuania. Survival rates show a negative trend. Four-year survival rate was only $54.91 \%$ in 2011 (as opposed to $65.98 \%$ in 2008 ).

Lack of business dynamics in the manufacturing sector compared to services may have a negative effect for the economy, because it implies a lack of initiatives to create significant innovations. Specifically, the nature of innovation is different in the service sector and manufacturing sector. The innovations in manufacturing industry is often connected to radical changes, while innovations in the service sector innovations are mainly related only to minor changes. The establishment of new enterprises can not only help to increase total employment, living standards and social well-being, but also to increase the comparative advantages of each sector due to higher competition. Knowing the firm dynamics of entry and exit and their determinants could serve as a guidance for economic policy creators, in order to achieve sustainable economic growth.

\section{References}

Acs, Z. J. (1992). Small Business Economics: A Global Perspective, Challenge, 35, November/December, pp. 38-44

Acs, Z. J. \& Audretsch, D. B. (2003). Handbook of Entrepreneurship Research, Springer Publishers, Boston

Ashcroft, B. \& Love, J. H. (1996). Firm Births and Employment Change in the British Counties: 1981-89, Papers in Regional Science, 75, pp. 483-500

Audretsch, D. B. \& Fritsch, M. (2002). Growth Regimes over Time and Space, Regional Studies, 36, pp. 113-124

Benic, D. (1997). The Role of Government in Transition Economies, Proceedings of DAAAM Second International Conference on Enterprise in Transition, Katalinic, B. (Ed.), pp. 41-46, ISBN: 3-901509-29-3, Brela, Croatia, May 1997, DAAAM International Vienna \& Faculty of Economics Split, Split - Brela

Carlsson, B. \& Eliasson, G. (2001). Industrial Dynamics and Endogenous Growth, DRUID, preliminary paper

De Jong, J. P. J.; Bruins, A.; Dolfsma, W. \& Meijaard, J. (2003). Innovation in Service Firms Explored: What, How and Why?, EIM Strategic Study B200205, Zoetermeer: EIM 
Kolakovic, M.; Sisek, B. \& Turuk, M.: Business Dynamics and Firm Survival in Eu...

Dunne, T.; Roberts, M. J. \& Samuelson, L. (1989). The Growth and Failure of U. S. Manufacturing Plants, The Quarterly Journal of Economics, 104 (4), pp. 671-698

Fritsch, M. (1996). Turbulence and Growth in West Germany: A Comparison of Evidence from Regions and Industries, Review of Industrial Organization, 11, pp. 231-251

Fritsch, M. (1997). New Firms and Regional Employment Change, Small Business Economics, Vol. 9, pp. 437-448

Fritsch, M. \& Mueller, P. (2004). The Effects of New Business Formation on Regional Development over Time, Regional Studies, 38, pp. 961-875

Geroski P. A. (1995). What Do We Know About Entry?, International Journal of Industrial Organization, 13, pp. 421-440

Johnson, P.S. \& Parker, S. (1996). Spatial Variations in the Determinants and Effects of Firm Births and Deaths, Regional Studies, 30, pp. 679-688

Ljubic, F. \& Covic, D. (2000). Democratic Society and Market Economy as the Determinants Growth enabling self-sustainable position of the State/Society, Proceedings of DAAAM 11th International DAAAM Symposium Intelligent Manufacturing \& Automation, Katalinic, B. (Ed.), pp. 322-324, ISBN: 3-901509-293, Opatija, Croatia, October 2000, DAAAM International Vienna

Meijaard, J. (2001). Making Sense of the New Economy, E-Commerce Research Forum, 2 (5), Massachusetts Institute of Technology, pp. 27-57

Nyström, K. (2006). Entry and Exit in Swedish Industrial Sectors, JIBS Dissertation Series No. 032, Jönköping International Business School: ARK Tryckaren

Nyström, K. (2007a). An industry disaggregated analysis of the determinants of regional entry and exit, The Annals of Regional Science, 41 (4), pp. 877-896

Nyström, K. (2007b). Patterns and determinants of entry and exit in industrial sector in Sweden, Journal of International Entrepreneurship, 5 (3-4), pp. 85-100

Phillips, B. D. \& Kirschhoff, B. A. (1989). Formation, Growth and Survival; Small Firm Dynamics in the U.S. Economy, Small Business Economics, 1 (1), pp. 65-74

Reynolds, P.D.; Hay, M.; Bygrave, W. D.; Camp, S. M. \& Autio, E. (2000). Global Entrepreneurship Monitor, 2000 Executive Report, Babson College, Wellesley, MA Schrör, H. (2007). Business demography: growth in the population of enterprises, Eurostat Statistics in focus, 48/2007

Schumpeter, J. A. (1934). The Theory of Economic Development, Harvard University Press, Cambridge, MA

Strotmann, H. (2007). Entrepreneurial Survival, Small Business Economics, Vol. 28, pp. $87-104$ 